\title{
Adaptive Capacity Assessment for A Flood Vulnerable Region through Land Use Modelling and Socio Economic and Physical Indicators
}

\author{
A. Narendr ${ }^{1}$, S. Das ${ }^{2}$, V. Shivamurthy ${ }^{1}$, and B. H. Aithal ${ }^{1}{ }^{*}$ \\ ${ }^{1}$ Ranbir and Chitra Gupta School of Infrastructure Design and Management, Indian Institute of Technology, Kharagpur 721302, India \\ ${ }^{2}$ Architecture, Town and Regional Planning, Indian Institute of Engineering Science and Technology, Shibpur 711103, India
}

Received 13 May 2020; revised 16 Jun 2020; accepted 28 Jun 2020; published online June 302020

\begin{abstract}
Resistance from climate extremes requires robust adaptation strategy, especially in regions that have greater density and limited resource availability. Weather extremes, such as anomalous precipitation leading to floods have now become a frequent global phenomenon. These situations could lead to unforeseen disaster if the region remains under-equipped to adapt against the vulnerabilities. Therefore, the research objective aims to explore the current status of adaptability within proposed capital region of Andhra Pradesh on backdrop of future urban growth that region may undergo. Andhra Pradesh Capital Region (APCR) has experienced severe flood events in past due to intense rainfall, overflowing Krishna river and causing inundation due to sudden releases from reservoirs upstream. An index based assessment of Mandalas were carried out by selecting relevant factors through various literature reviews. The method comprises of assigning comparative scores to the mandals based on their performance for each parameter and categorizing them on a Likert scale of 1 to 5 . The selected parameters are then prioritized by adding weights through pairwise comparison techniques using Analytical Hierarchical Process. Risk Map for the region was developed using weighted sum of flood vulnerability factors and urban development scenario of 2050. The results substantiate that the regional vulnerability is cumulatively influenced by exposure and sensitivity factors. The empirical findings identify female literacy and elevation as major contributor to flood vulnerability. Requirement for immediate interventions were suggested for the mandals with higher vulnerability and greater scope of urban transformation. The proposed method will help in quick identification of susceptible mandals that may suffer higher vulnerability in future. The method proposed will also be effective for formulation policies for redirecting scarce resources in areas needing adaptation against climate disasters.
\end{abstract}

Keywords: adaptive capacity, green field development, index-based method, urban transformation, vulnerability assessment

\section{Introduction}

Conceptual theory of adaptation was correlated with the biological behaviours of species to adjust within the hostile climate. Adaptation function is though different from mutation and natural selection that are more of genetic convolutions, it is adjustments based on past experiences. The human systems are ingrained with skills of instinctive adaptation as a response to critical stimuli. The chosen responses may often not be the best fit or maybe a 'mal-adaptation' to the problem that can further deteriorate the situation in the longer term. Nevertheless, humans also possess the ability of futuristic thinking as a part of a responsive mechanism. They arrive at conclusions based on rational evidence from the past and estimating their robustness in the future. Such adaptations are planned actions or sustainable adaptation measures as a response to disaster-inducing stimulus (Engle, 2011). Adaptation concepts has been widely used in disciplines such as evolutionary science, anthropology

* Corresponding author. Tel.: +91-3222-304944; fax: +91-3222-304944

E-mail address: bharathhaithal@gmail.com (B. H. Aithal)

ISSN: 2663-6859 print/2663-6867 online

(C) 2020 ISEIS All rights reserved. doi:10.3808/jeil.202000031. and cultural ecology, social science, political ecology, etc. However, adaptation to climate change refers to subduing or mitigating its effect through animation of cognitive scenarios (Smit and Wandel, 2006).

Smit and Wandel (2006) broadly classified 'adaptation to climate change' studies under two categories. The first group of study is for identifying an adaptation strategy or choosing the best from series of given alternatives through rational analysis. The second group of study focuses developing "practical adaptive initiatives" customised as per the needs of a particular society. An important category of adaptation studies is also based on evaluating the relative adaptive capacity (or vulnerability) of countries, regions, or communities, and involves comparative evaluation or rating based on criteria, indices and variables typically selected by the researcher. Here, the main aim is to frame policies meant for resilient growth that also tap climate change opportunities in areas with the poorest adaptive capacity.

Adaptive capacity is a system characteristic to develop an analogy for redirecting its scarce resource in response to the stressful events over futuristic cogitations. It is also an analysis of limitations that restrict these responses from being universally applicable and sustainable such as constraints regarding 
resource distribution and containment (IPCC, 2001; Folke, 2006). Brooks and Adger (2005) defined its as a system property to ensure better coping ability against present and anticipated climate extremes or variabilities. Climate extremes are weather anomalies that occur due to large deviation of a weather events from its usual observed value (Banholzer, 2014).

Climate change has evolved life on earth since time immemorial. However, since the last century, the changes have been rapid, bearing negative impacts on human beings and environment (Alley et al., 2003). This is due to exhaustive and unsustainable use of natural resources by the people. Therefore, uncertainties and predictability associated with climate changes are becoming complex resulting into frequent anomalies. Such variation in intensities is a serious issue of concern in planning and developmental processes (or projects) and needs to be addressed with caution and utmost priority, negligence in understanding may lead to catastrophic failures.

A hazard becomes a disaster/catastrophe when it leads to loss of life and property (Wisner et al., 2004). Consequently, a disaster is a product of intensity of hazard and risk associated to human life and environment (Eiser et al., 2012). Evaluation of adaptive capacity needs vary with scale, demography, physiography, and hazard being addressed. The process begins with identifying the dominant hazard within the region, its effect on the most vulnerable population and assessment of factors conditioning regional vulnerability. As per the IPCC 2001 report, the adaptive capacity has an inverse relation to system vulnerability. Vulnerability of a system is measured through its sensitivity towards adverse effects of climate change depending upon the exposure it has and its capability to resist or adapt.

The Indian subcontinent has faced highest number of disaster events in the entire South-East Asia, among which floods are the most frequent ones (Gupta, 2009). Forty million hectares of the entire mainland is susceptible to floods, with approximately 8-million-hectare experience floods every year (De et al., 2005). Seventy-six percent of the entire peninsular coastline is highly vulnerable to tropical cyclones (Nair et al., 2013) and fiftynine percent of the subcontinent is prone to seismic hazards. In the year 2009, multiple states, namely Andhra Pradesh, Maharashtra, Karnataka, Kerala in the South, Orissa in the East and Delhi at the North, were affected by severe floods during the monsoons. The 2009 floods affected about 29 million inhabitants across the country and damaged residential properties worth up to 100 billion USD which the highest damage recorded between 2004 to 2013 (CWC, 2015; Tripathi, 2015). Kedarnath in Uttarakand faced floods in the year 2013 was yet another alarming impact of human interventions on flood plains, natural vegetation etc. affecting almost 6,000 people in the districts of Rudraprayag, Chamoli, Uttarkashi and Pithoragarh (Akhtar and Farooq, 2017). Variations in monsoons with intense and irregular rainfall events also has devastating effects such as flash floods, witnessed in Arunachal Pradesh, Assam, Orissa, Himachal Pradesh, Utta-rakhand, the Western Ghats from Gujrat and Tamil Nadu. Often the downstream states such as Assam, Bihar, Uttar Pradesh, Odisha, and Andhra Pradesh have experienced floods due to sudden water releases from dams and reservoirs (Nandargi and Dhar, 2003)
Realizing the consequences, the Indian government have come up with several disaster resilient plans in line with various international initiatives such as Sendai framework. The framework was adopted for year $2015 \sim 2030$ with an aim to mainstream disaster risk resilience by analysing differential risk and adaptive needs. In the 12th five-year plan, the government of India prioritised investment on disaster prevention and mitigation over post disaster responses considering its social and economic benefits. The National Action Plan on Climate Change (NAPPCC) launched in 2008 was the first in-house initiative for combatting disasters caused due to weather extremes within the country. It was further launched at various state levels in order promote planned adaptation through the means of technical innovation, increasing awareness, restoring critical infrastructure etc. For reducing vulnerability due to climate extremes such as floods. (Planning Commission, 2011; Byravan and Rajan, 2013).

Floods can be categorised into natural and anthropogenic, depending on the factors of stimulation and the areas they affect. A flood event termed natural when it occurs due to the sudden effect of a natural disaster, such as cloud burst, cyclone surge or blocking of river channels due to landslide. On the contrary, a flooding event turns out to be a man-made disaster when it is a result of an anthropogenic activity or human callousness, such as dam bursts, changes in land use leading to floods and inundation of low-lying areas (Nied et al., 2014).

Table 1. Urban Flood Events in the Past (Sarmah and Das, 2018)

\begin{tabular}{ll}
\hline Cities & Year of occurrence \\
\hline Ahmedabad & 2001,2017 \\
Bengaluru & $2005,2009,2013$ \\
Chennai & $2004,2005,2015$ \\
Delhi & $2003,2009,2010,2013,2016$ \\
Gandhinagar & 2017 \\
Guwahati & $2010,2011,2015,2016,2017$ \\
Hyderabad & $2000,2001,2002,2006,2008$ \\
Jamshedpur & 2008 \\
Kolkata & 2007 \\
Mumbai & $2005,2007,2015,2017$ \\
Srinagar & $1992,2014,2015$ \\
Surat & 2006 \\
\hline
\end{tabular}

Apart from the floodplains, some of the densely populated regions in the country have shown rising sensitivity towards urban floods. Cities (in Table 1) are suffering due to prolonged inundation due to the alteration of natural drains. This is mainly because of haphazard urbanization, proliferation of slums and unabated construction activities in the valley zones and flood plains of the catchment areas (Ramachandra et al., 2012; Sarmah and Das, 2018). Urban flood event is rising even during normal rainfall events, which can be attributed to possible result of reckless development on the flood plains (Ramachandra et al., 2012). The low-lying areas that earlier served as wetlands have now transformed into impervious sheaths of urban morphology with subdued concerns about the environment and city welfare.

Flood hazard vulnerability corresponds to both its mag- 
nitude and duration which affects an individual, society, organization and/or environment. 'Vulnerability assessment' of flood hazard is a preparedness technique to ensure disaster risk reduction. It will enable policymakers to identify the region's susceptibility based on its exposure, sensitivity, and adaptability towards climate extremes. Therefore, assessment of flood hazard characteristics and elements at risk is indispensable for a rational intervention in process of resilient development.

Vulnerability assessment due to flood follows two distinct methods of analysis:

i. Deterministic Modelling Approach. It evaluates flood situation and its probability of occurrences with the help of physically based models. Hydrograph are created using long term data, which is then used by a 1- or 2-dimensional hydrologic computer model to derive future flood scenario. These hydrologic models are capable of predicting flow characteristics such as velocity, height and extent, are paired with damage assessment model to estimate total flood loss for a region.

ii. Parametric Approach. Flood analysis relies on the conception of limited data availability. The method believes in exploring absolute vulnerability by employing readily available data stacks. The vulnerability of a region is believed to be interdisciplinary; therefore, factors are taken from several different domains such as social, economic, physical and many more. The methodology is designed to involve experts' opinion for evaluation of vulnerability; however, all of its assumptions cannot be validated through field observations.

Balica et al. (2013) considered the parametric or indicator- based approach more appropriate tool for decision making over others because of its better representation of social, economic and infrastructure stature. They have a more comprehensive scope and can be easily applied, worked upon and compared for different vulnerable locations. They are the human-centric way of planning resilience that will help in identifying the priority of work for risk reduction. Similarly, Connor and Hiroki et al. (2005) believe that flood vulnerability cannot be limited to hydrological phenomena such as precipitation and runoff. The process is incomplete without assessing the preparedness level and adaptive capacity of the exposed group. Rufat et al. (2015), through a meta-analysis of 67 elements concluded demographic, socio-economic, and health characteristics of population to be indispensably related to disaster vulnerability in case of floods. Similar study by Lee et al. (2013) has developed climate-extreme resilient framework consisting of indicators that express social vulnerability at different spatial scales.

The current study aims to explore the adaptive capacity of each of the "mandals" against reoccurring flood events within the Andhra Pradesh Capital Region. Mandals act as the administrative boundaries within the proposed greenfield capital region. The study is based on an evaluation of relevant sociophysical parameters in an indicator-based vulnerability assessment process to derive vulnerability score for the region. Later the score is put along with predicted land use map of 2050 (Bharath et al., 2017) to delineate hotspots needing major adaptation for sustainability. The hotspots are highly vulnerable areas with the potential of higher density, thus greater exposure to flood hazards in coming future.

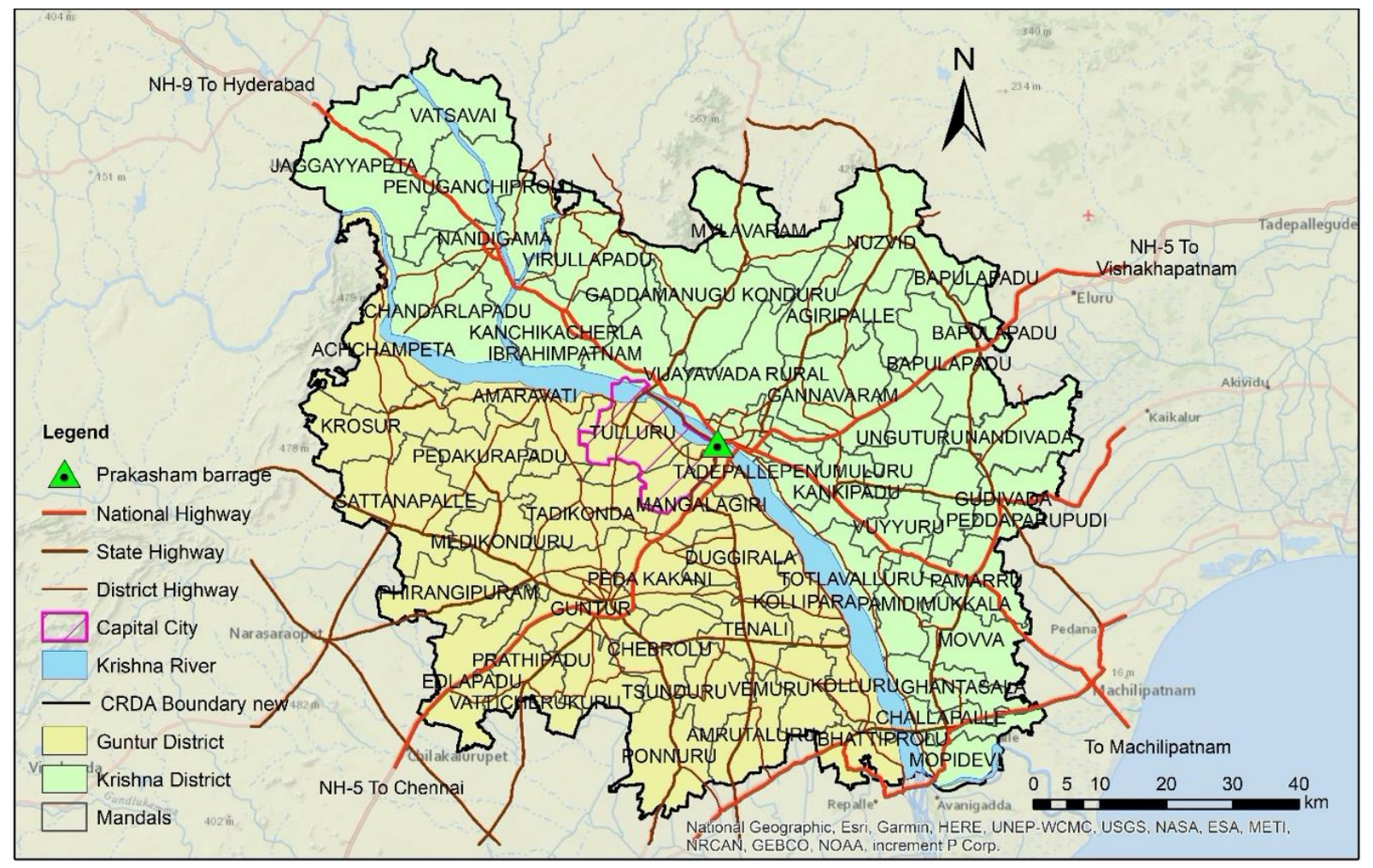

Figure 1. Regional map of APCR. 


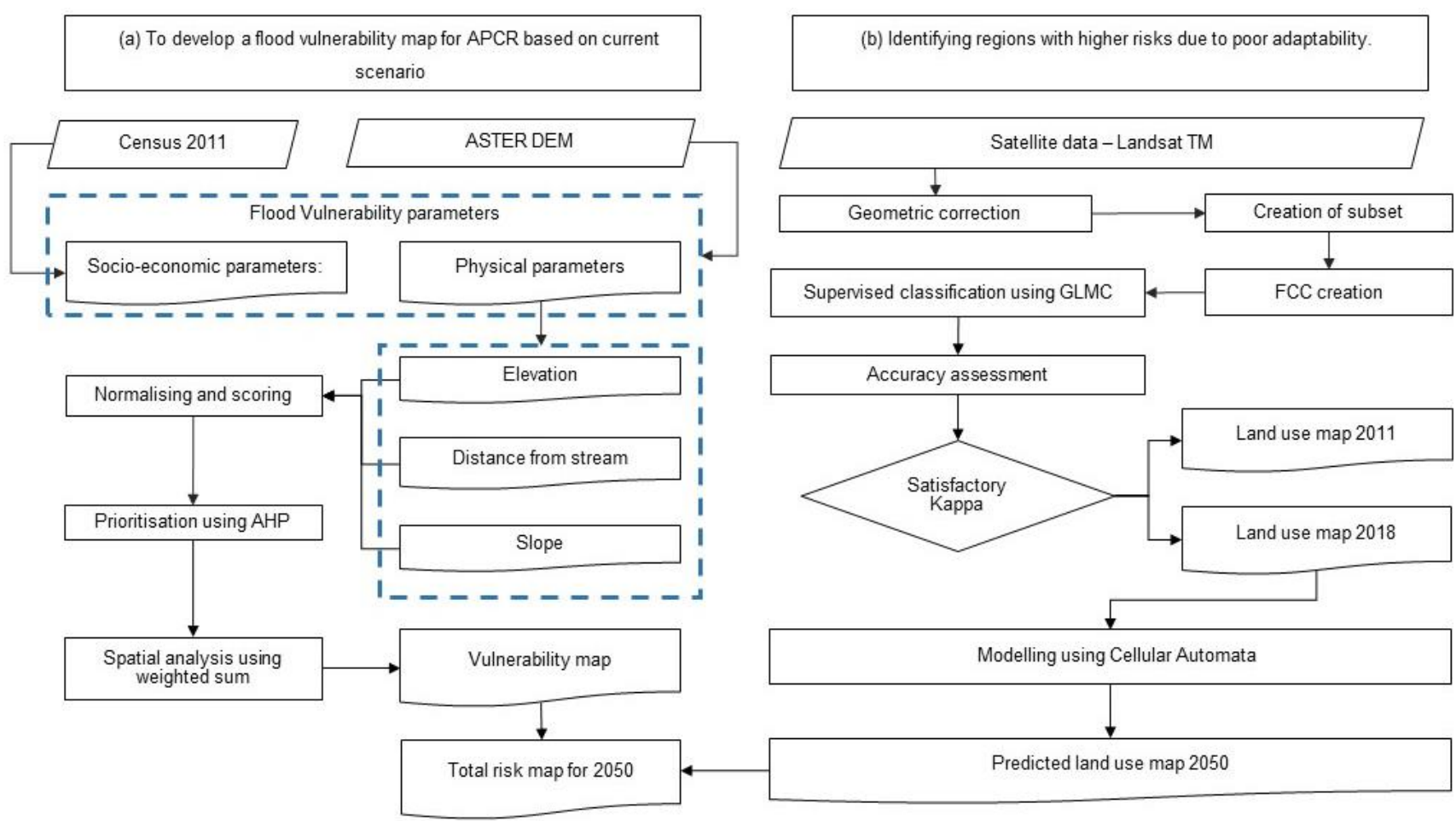

Figure 2. Method used in the analysis.

Table 2. Data Used in the Analysis

\begin{tabular}{|c|c|c|}
\hline Purpose/Data type & Year & Data source \\
\hline Land use analysis & 2011,2018 & $\begin{array}{l}\text { Landsat series thematic mapper }(28.5 \mathrm{~m}) \text { and enhanced thematic } \\
\text { mapper sensors }\end{array}$ \\
\hline Boundary and base layers. & 2018 & $\begin{array}{l}\text { Capital region development authority (CRDA), government of } \\
\text { Andhra Pradesh (website) }\end{array}$ \\
\hline Elevation, slope and stream network & 2011 & ASTER global digital elevation model V002 (30 m) \\
\hline $\begin{array}{l}\text { Mandal wise (population density, female literacy, } \\
\text { details on health infrastructure, kutcha house } \\
\text { density, strength of marginal workers and } \\
\text { accessibility of mandals) }\end{array}$ & 2011 & $\begin{array}{l}\text { - Census data } \\
\text { - Capital region development authority (CRDA), government } \\
\text { of Andhra Pradesh (website) \& capital region development } \\
\text { authority, government of Andhra Pradesh }\end{array}$ \\
\hline
\end{tabular}

\section{Study Area and Its Criticality}

Andhra Pradesh Capital Region (APCR) restructured in the year 2012 from the state of Andhra Pradesh is critically chosen for such adaptive capacity assessment process. APCR covers an area of about $8,603 \mathrm{~km}^{2}$. These districts comprise of sub-administrative units or the revenue divisions called 'Mandals'. There are 56 Mandals within the APCR administrative boundary. A greenfield capital city development project of about $217 \mathrm{~km}^{2}$. For the newly formed state of Andhra Pradesh, 'Amaravati' has been proposed in close proximity to Vijayawada and exactly at $200 \mathrm{~km}$ from Guntur Mandal (Andhra Pradesh Capital Region Development Authority, 2017). The capital city is located on the Southern bank of the river Krishna, that bifurcates the entire APCR into two districts, namely Krishna and Guntur district. The region is vulnerable because (a) the area is traditionally susceptible to flooding from the river Krishna and several other multi-purpose irrigation projects; (b) the monsoon driven agrarian society has low Human Development Index (HDI) rank (27th out of thirty-six states and union territories); and (c) the region is at the brink of boundlessgreenfield development due to recent constitution of state including upcoming capital city of Amaravati.

Figure 1 represents the strategic location of the newly delineated APCR. The region is closer to the Eastern coast of India and has been facing a series of flood-related issues over decades. For instance, APCR experienced massive flooding in October 2009, due to the unprecedented rainfall, spilling river Krishna and its tributaries. The Krishna river basin received 25.4 lakh cusecs of discharge that was way beyond the previous highest flood record of 9.32 lakh cusecs in October 1998 at Vijayawada (APWRC, 2009). The study area also has boon or bane of several irrigation projects such as, Nagarjuna Sagar dam on the river Krishna was constructed in 1967 with a gross storage capacity of 11.472 billion cubic metres, Velagaleru regulator on the nearby Budameru river constructed in 1960 was 
supposed to divert excess floodwater, is still havoc due to its insufficient capacity than the observed peak discharge.

Agriculture is the primary source of income within the region; frequent flood events cause a detrimental effect on the monsoon-driven economy and social status of those associated. Above all, the district handbook data from census of India confirms the inferior status and inequitable distribution of social and physical infrastructure within the region with substantially limited state of awareness and lower literacy standards. For instance, the average female literacy across the Guntur region is about $39 \%$ and within entire APCR is $53 \%$ way below the national average of about $64 \%$ (Census of India, 2011). Hence, the research work aims to examine present status of flood vulnerability in the region along with concerns regarding upcoming threats that may arise with rapid development and population growth.

\section{Data and Methods}

The present study determines differential adaptability requirement for a flood resilient development through spatial mapping of proposed APCR. The existing greenfield development area is certain to undergo a massive transformation to built-up area in the coming years. Therefore, the task here is to characterize the present vulnerability profile along with prioritising the future adaptation need for the region. The assessment is based on a mandal wise evaluation from the set of key parameters chosen from physical, social and economic domains.
Land-use prediction for the year 2050 further helps in understanding the brewing challenges around emerging growth centres that will affect their sustainability in absence of resilient planning strategies.

The predictive method shall benefit resource crunched region that face the 'backwash' effect due to inequitable distribution. Therefore, this study aims to identify sub-administrative units, within the study area, that are likely to suffer a higher exposure because of their socio-economic in capabilities and proposed regional development plan.

Figure 2 showcases the steps involved in development Total Risk Map for the year 2050. The method can be subdivided into two broad objectives: (i) to develop a flood vulnerability map for APCR based on current scenario; and (ii) identifying regions with higher risks due to poor adaptability.

\subsection{Data Collection and Extraction of Features}

The socio-economic data used for developing the flood vulnerability conditioning factors were taken from the 2011 Census of India district handbooks (Krishna and Guntur districts) and also from mandal wise data available on the Capital Region Development Authority (CRDA), Government of Andhra Pradesh website. The physical factor such as elevation and slope were extracted using ASTER DEM data set. The DEM was also used for plotting natural drainage pattern and stream network within the region. The elevation, slope and distance from stream were ranked into five classes depending on their

Table 3. Description of Factors Considered

\begin{tabular}{|c|c|c|c|}
\hline S. no. & Factors & Relevance to the context & $\begin{array}{l}\text { Effect on the regional } \\
\text { vulnerability }\end{array}$ \\
\hline 1. & Accessibility & $\begin{array}{l}\text { Accessibility within a mandal determines resource mobility within it at the } \\
\text { occurrence of extreme events. It can be related to both evacuation and relief } \\
\text { processes. }\end{array}$ & Reducing $(\downarrow)$ \\
\hline 2. & Population density & Higher the population per unit area more are they exposed to hazard threats. & Inducing $(\uparrow)$ \\
\hline 3. & Female education & $\begin{array}{l}\text { It is concerned with the awareness among the women and children about the } \\
\text { risks associated with natural disasters. Female mortality during a disaster is } 14 \\
\text { times higher than that of men. The Sendai Framework objectively puts forth this } \\
\text { issue of gender inequality in the global motto of disaster risk reduction. (UNDP, } \\
\text { 2013) }\end{array}$ & Reducing $(\downarrow)$ \\
\hline 4. & $\begin{array}{l}\text { Health } \\
\text { infrastructure }\end{array}$ & $\begin{array}{l}\text { Presence of public sponsored health infrastructure in the region ensures that the } \\
\text { marginalized citizens can hope for a better recovery in a disaster struck } \\
\text { environment. }\end{array}$ & Reducing $(\downarrow)$ \\
\hline 5. & $\begin{array}{l}\text { No. of kutcha } \\
\text { houses in a mandal }\end{array}$ & $\begin{array}{l}\text { Kutcha houses are non-engineered houses built from materials such as thatched } \\
\text { huts usually made of mud, straw, bamboo or other non-durable materials. They } \\
\text { have a higher tendency to crumble during torrential rain and flooding. (GOI, } \\
\text { 2011) }\end{array}$ & Inducing $(\uparrow)$ \\
\hline 6. & $\begin{array}{l}\text { No. of marginal } \\
\text { worker population } \\
\text { in a mandal }\end{array}$ & $\begin{array}{l}\text { It is the worker population that works for a duration of fewer than six months in } \\
\text { a year (GOI, 2011). An agrarian economy has land-less labours who do not have } \\
\text { permanent employment or source of income in most of the year. }\end{array}$ & Inducing $(\uparrow)$ \\
\hline 7. & Slope & $\begin{array}{l}\text { Areas with lower slope value or at a flatter terrain is more susceptible to } \\
\text { inundation rather than those located at a higher terrain. }\end{array}$ & Reducing $(\downarrow)$ \\
\hline 8. & $\begin{array}{l}\text { Distance from the } \\
\text { stream }\end{array}$ & $\begin{array}{l}\text { The proximity to the river is associated with flood vulnerability in case of } \\
\text { overflow, surge, and erosion of edges during peak flows. Here, river along with } \\
\text { its tributaries are streams }\end{array}$ & Reducing $(\downarrow)$ \\
\hline 9. & Elevation & $\begin{array}{l}\text { The settlements at higher elevations are less likely to affecte by floods than } \\
\text { those living on flood plains or delta of the river. }\end{array}$ & Reducing $(\downarrow)$ \\
\hline
\end{tabular}


susceptibility to flood. Regional map plan was geo-registered to extract boundary details for APCR, seed capital, water bodies and major roads layouts within. Remote Sensing data for land use analysis were acquired from Landsat Series for the years 2011 and 2018. Data type and respective sources are mentioned in Table 2.

\subsection{Data Processing and Analysis}

Objective 1 includes selection of key parameters based on on-site observations, focused group discussion and review of literature on similar topics. The chosen parameter complies with the following criteria of data availability and authenticity of data sources. Parameter selection is followed by a relative scoring and mapping of mandals based on the assigned ranks. The highest values for the respective parameters are identified and used as a common divisor for relative scoring. The mandal score hence obtained is categorised using a Likert scale (Wang et al., 2018) within a range of 1 to 5:

Mandal score $=V_{j} / V_{j \max }$

where $j=$ parameter value for a Mandal; $j \max =$ highest parameter value for a Mandal.

Evaluation was carried out using nine broad parameters such as (i) elevation of the region; (ii) distance from the stream; (iii) mandal wise population density; (iv) female literacy; (v) presence of health infrastructure; (vi) accessibility in the mandal; (vii) slope in the region; (viii) number of kutcha houses; and (ix) number of marginal worker population in a mandal. The social indicators considered for analysis were similar to those mentioned under the guidelines of the State Action Plan on Climate Change for Andhra Pradesh (MoEF, 2012).

The mandals with higher vulnerability will bear a lower score compared to those having a lesser vulnerability to floods. The scoring pattern is kept such that it assigns higher scores to the 'vulnerability-reducing' $(\downarrow)$ type factors and vice-versa in the case of factors that 'induce' $(\uparrow)$ disaster vulnerability in a mandal. The mandal with the least score will have a higher risk or poor resilience than other higher-scoring mandals. Each factor with its relevance in the assessment process has been explained in Table 3.

The second step is prioritising of chosen parameter based on the experts' opinion relative to their sensitivity towards flooding. The priority scores obtained is put into an Analytical Hierarchical Process (AHP) matrix to derive weights for each parameter. AHP uses a pairwise comparison matrix $\mathrm{R}$ of the size $m \times m$, where $m$ is the number of parameters to be evaluated (Saaty, 2008). For every input $r_{i j}$, the matrix evaluates sensitivity of $i$ th parameter over the $j$ th parameter towards flood vulnerability. The relative sensitivity of parameter is assigned between 1 to 9 point scale having the following explanations (in Table 4). The value of $r_{i i}$ and $r_{j j}$ will be 1 for all $i$ and $j$ and it is also viable to assign the intermediate value for an explicit explanation.

The assigned weights are used for computing normalized
Eigen vectors (global weight) across each parameter (rows) by normalizing the matrix and dividing the sum of each normalized rows by the number of parameters being considered for evaluation from Equations (2) and (3). Normalizing using column sum:

$R=r_{i j} / \sum r_{c l j}$

Global weight $\left(w_{0}\right)=\sum r_{\text {Roi }} / m$

where $r_{i j}=$ matrix value at the respective $i$ th row and $j$ th column, $\Sigma r_{c l j}=\operatorname{sum}$ of column $j, \Sigma r_{R o i}=\operatorname{sum}$ of row $i(i$ and $j=1, \ldots, m)$.

Table 4. Relative Scaling

\begin{tabular}{ll}
\hline Value of $r_{i j}$ & Explanation \\
\hline 1 & $i$ and $j$ are equally sensitive \\
3 & $i$ is moderately more sensitive than $j$ \\
5 & $i$ is more sensitive than $j$ \\
7 & $i$ is strongly more sensitive than $j$ \\
9 & $i$ is absolutely more sensitive than $j$ \\
\hline
\end{tabular}

The inconsistency level allowed for the matrix is obtained by estimating the consistency index. The global weight is multiplied each value in the column of an un-normalized matrix $\boldsymbol{R}$ to obtain matrix $R_{0}$ from Equation (4). The summation of each row value of the $R_{0}$ matrix is divided by respective global weights $W_{0}$ to obtain $\lambda_{0}$ for each row in Equation (5). The $\lambda$ max is calculated by averaging $\lambda_{0}$ for the chosen set of parameters that is used for calculating consistency index from Equation (6):

$\operatorname{matrix}\left(\boldsymbol{R} \cdot W_{0}\right)=R_{0}$

$R_{0}\left[\sum r_{R o i}\right] / W_{0}=\lambda_{0} r_{R o i}$

where $R_{0}\left[\Sigma \mathrm{r}_{\text {Roi }}\right]=$ summation of row $i$ in matrix $R_{0}, \lambda_{0} r_{R o i}=$ ratio for each row:

$\lambda \max =\sum \lambda_{0} / m$

Consistency Index $(C I)=(\lambda \max -m) /(m-1)$

The consistency index is used for calculating consistency ratio by dividing it with random index value depending upon the number of parameter chosen for analysis. The consistency ratio values near zero show good consistency. The model was calibrated to derive the consistency ratio of 0.09 .

The global weights obtained are used for spatial analysis of parameters using the weighted sum technique mentioned in Equation (8). Execution of method will follow overlaying of individual parameter maps along with their global weights to delineate flood vulnerability for the current scenario.

The vulnerability is overlaid by predicted land use map 2050 to visualise emerging needs for adaptation: 
Flood Vulnerability Map $=\sum\left(a_{0} x_{0}+a_{1} x_{1}+\cdots+a_{9} x_{9}\right)$

where $a_{i}=$ Global weight of the factor; $x_{i}=$ name of the factor

Development of the flood vulnerability map gives out scope for the second objective. It begins with pre-processing of temporal data acquired for year 2011 and 2018 from Landsat series satellite of United States Geological Survey (USGS).

The pre-processing includes geometric correction to eliminate image distortions and developing a subset based on the administrative boundary extent mentioned by CRDA, Government of Andhra Pradesh official website. The next step is to create a False Colour Composite (FCC) to understand the re- gional heterogeneity and this information is further used to collect signatures into the following prominent landuse classes.

Land use classification was carried out using Gaussian Maximum Likelihood Classifier (GLMC) by classifying the data to five land use classes (Table 5). Accuracy assessment of land use classifications is performed using field observations and secondary data from the virtual earth data bases though overall accuracy and kappa statistics (Bhat et al., 2015; Nimish et al., 2018), 60\% of the training data were used for classification and $40 \%$ were used for accuracy assessment.

The land use map of 2011 and 2018 were used in the rule based Cellular Automata (CA) model for predicting likely urban growth in 2050 of the region. Cellular Automata (CA)

Table 5. Land Use Class Description

\begin{tabular}{ll}
\hline Land use class & Land uses included in the class \\
\hline Built-up & $\begin{array}{l}\text { This category includes residential area (rural as well as the urban settlements), industrial area, and all paved surfaces and } \\
\text { mixed pixels having built-up area. }\end{array}$ \\
Vegetation & Protected forest area in the region, sown agricultural field, nurseries \\
Water body & River, aquacultures, tanks, lakes, reservoirs. \\
Others & Fallow land, rocks, quarry pits, open ground at building sites, barren land, kutcha roads, and river bed (dry).
\end{tabular}

(a) Accessibility $(\downarrow)$

Wt.-0.111

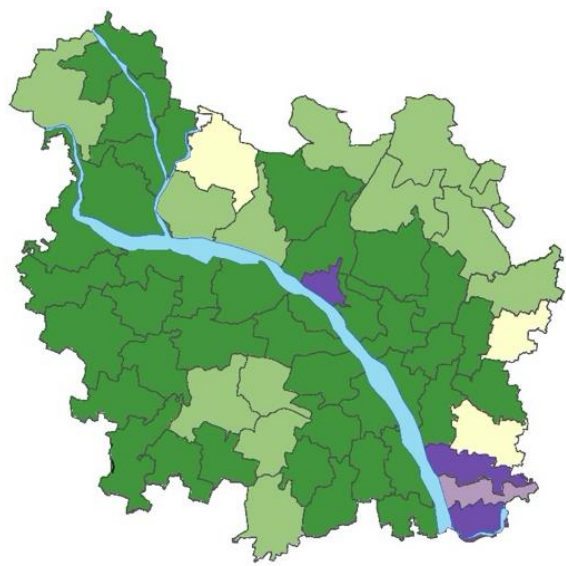

(c) Female Education $(\downarrow)$

Wt.-0.271

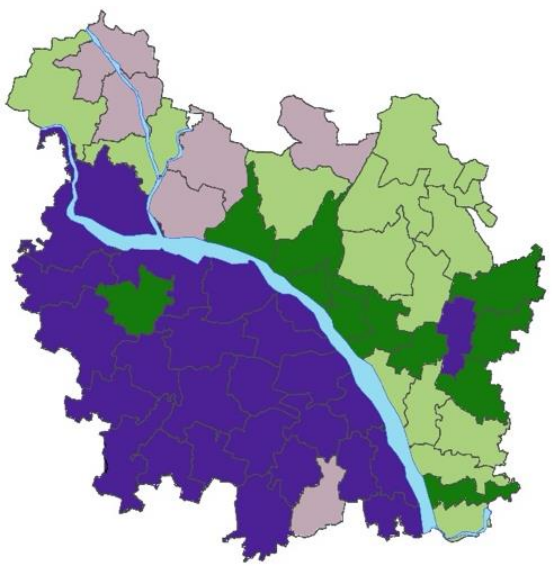

(b) Density $(\uparrow)$

Wt.-0.021

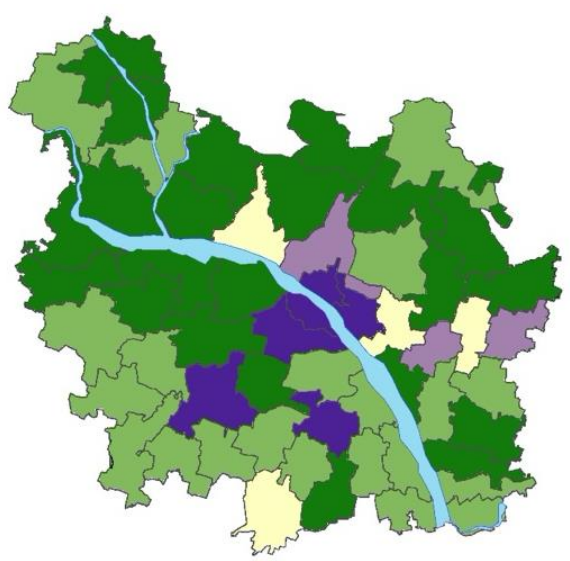

(d) Health Infrastructure $(\downarrow)$

Wt.-0.146

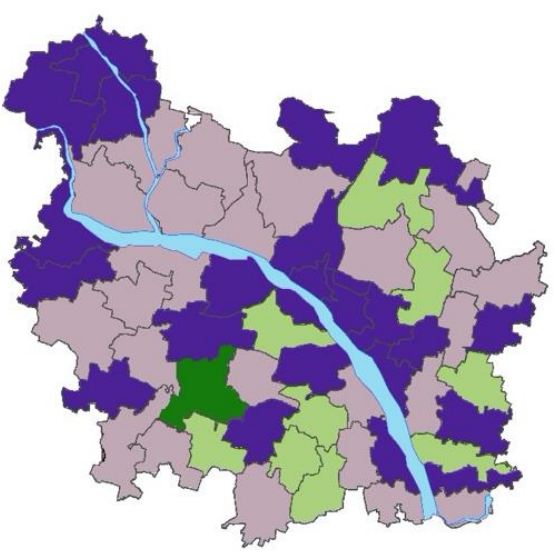


(e) No. of Kutcha house in a Mandal $(\uparrow)$

Wt.-0.068

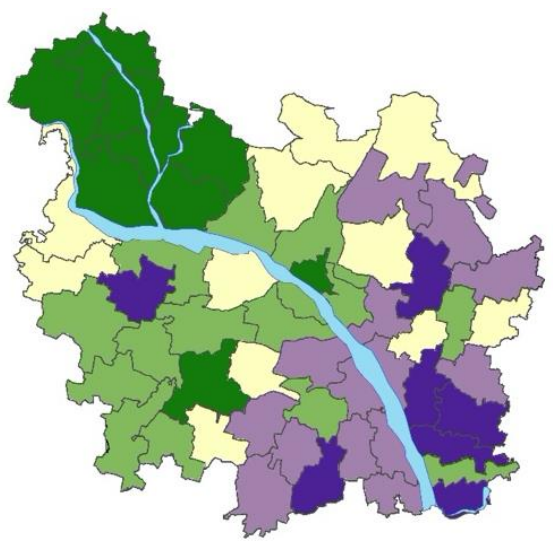

(g) Slope $(\downarrow)$

Wt.-0.047

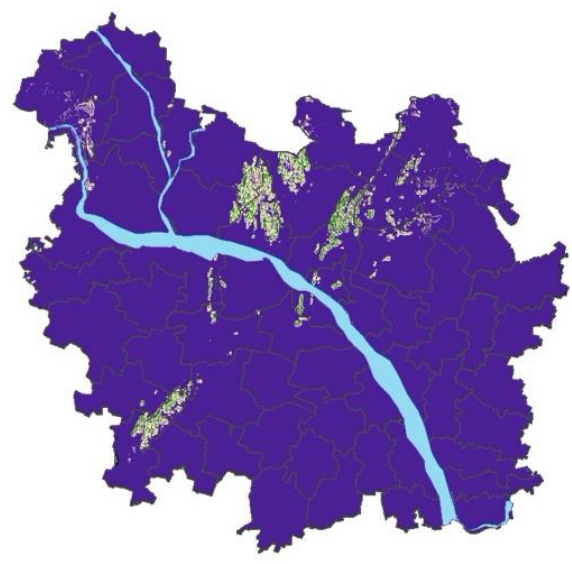

(i) Elevation $(\downarrow)$

Wt.-0.261

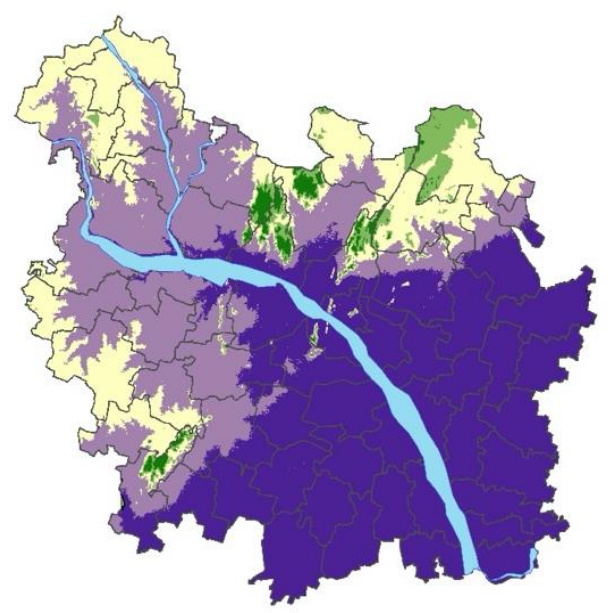

(f) Marginal worker population $(\uparrow)$

Wt. -0.036

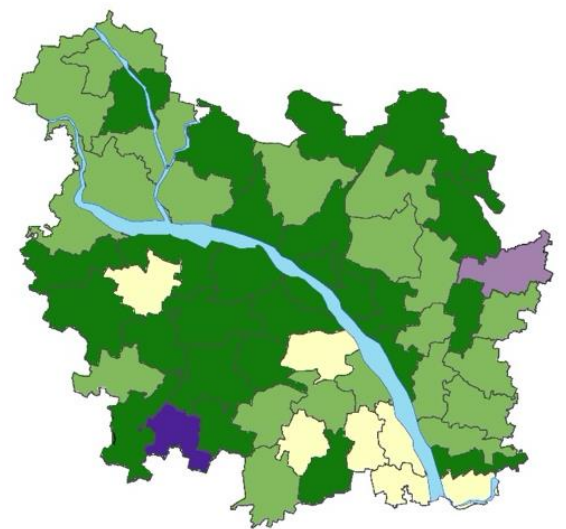

(h) Distance from the stream $(\downarrow)$ Wt.-0.035

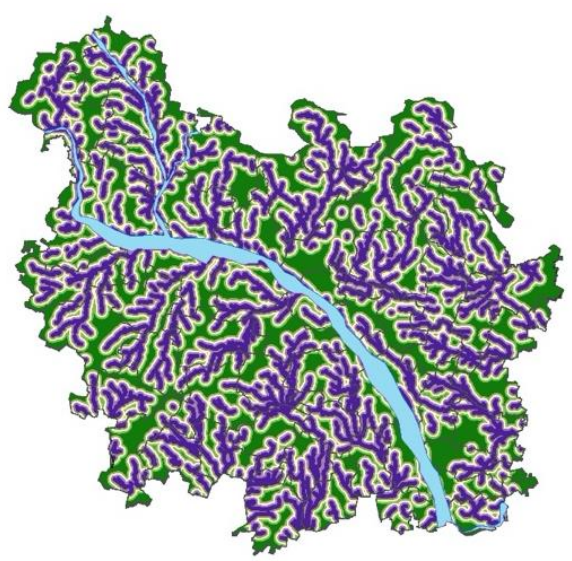

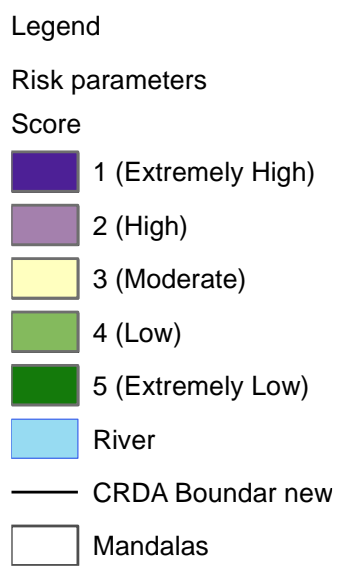

Figure 3. Spatial representation of parameters used for flood risk identification in APCR. (a) Accessibility; (b) Density; (c) Female education; (d) Health Infrastructure; (e) No. of Kutcha house in a Mandal; (f) Marginal worker population; (g) Slope; (h) Distance from the stream; (i) Elevation. 
(a) Land use of APCR year 2011

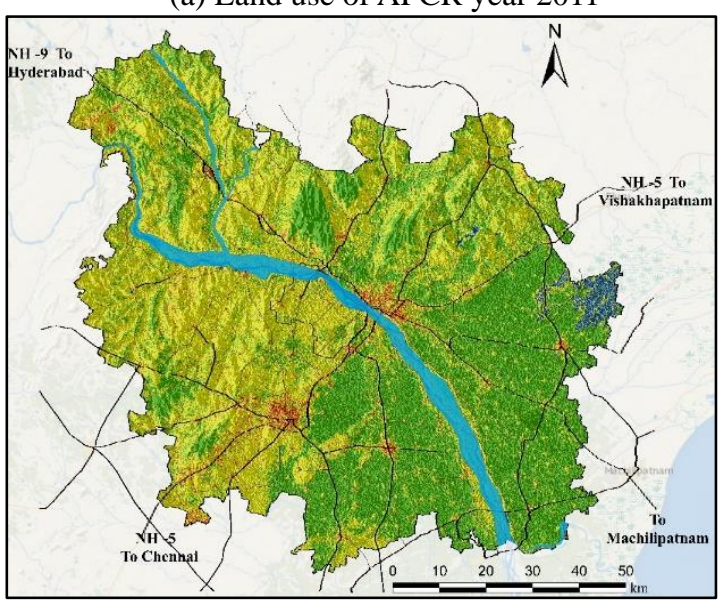

(c) Land use of APCR year 2050

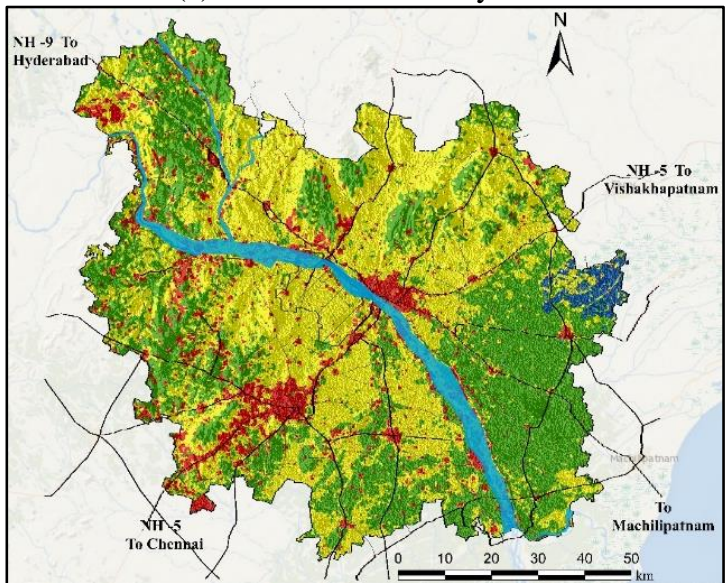

(b) Land use of APCR year 2018

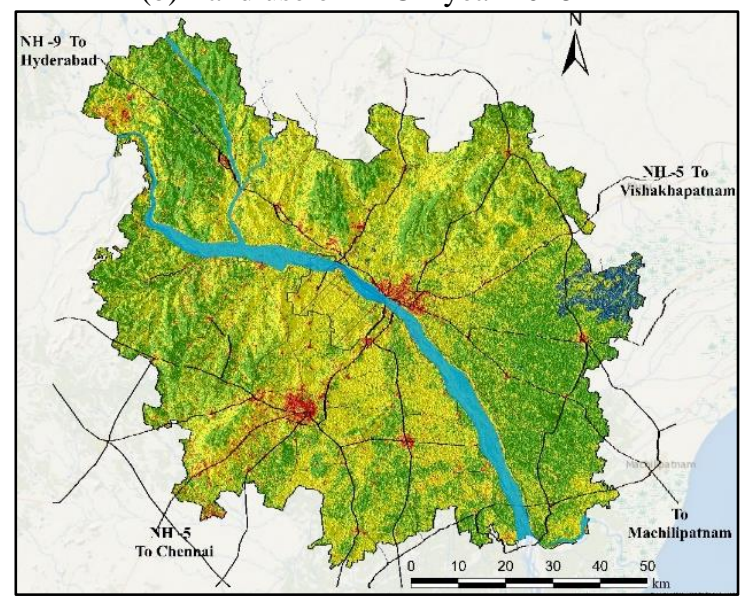

Figure 4. Land use analysis and visualization of land use for year (a) 2011; (b) 2018; (c) 2050.

explains the change in the state of a cell by analysing the state of its neighbouring cells. The analogy adheres to the given set of transformation rules. CA was the most commonly used methodology between 1996 to 2007 (Lantman et al., 2011) due to its simplicity of use and highly accommodating spatial datasets handling features. The built-up layer is extracted from the predicted map of 2050 to visualise the adaptation needs subject to present flood vulnerability in the region.

\section{Results and Discussions}

\subsection{Analysis of Regional Vulnerability}

Figure 3 (a-i), elaborates the performance or the adaptive capacity of different mandals. Social parameters such as accessibility, female education and health infrastructure serve as reducing agents for being negatively related to regional vulnerability. Densely populated regions, the presence of kutcha houses and marginal worker population increase vulnerability due to higher exposure and reduced coping capacity towards flood hazard. However, areas located at higher elevations, and at a greater distance from streams will be safer during floods because of limited hazard exposure.
Multi criteria evaluation assigns the highest score to female literacy as this factor correlates to awareness regarding flood phenomenon, its occurrences and effects, preparedness, mitigation, and adaptation knowledge within the region. This novel idea is supported through assessments of Azad et al. (2013) and Hamidazada et al. (2019), elaborating on varying vulnerability among genders. Lack of awareness among women add to their existing plight as they remain unable to utilize resources such as information regarding early warning, access to relief material, government sponsored health benefits and relief allowances in pre and post disaster scenario. Additionally, hazard susceptibility among mothers' negatively affect safety and well-being of their children (Madhuri, 2016; Islam, 2017).

Similar to this, elevation is the second most important parameter that influence the vulnerability of a region by governing the level of hazard exposure within the settlement. Presence of adequate health infrastructure and accessibility enhances the robustness of a region by facilitating the ease of treatment and quick evacuation during a flood emergency. Likewise, areas with high population density and those located at flatter terrains, closer to flood plain have increased chances of inundation due to exposure. Marginal worker population and deprived sections 
of society suffer the most because of lack of affordability for resilient alternatives.

\subsection{Prediction of Future Risk Map}

The temporal land use classifications consider built-up class to be as impermeable areas irrespective of their urban/ rural location. The built-up area was about $2.06 \%$ in 2011 has increased to $3.82 \%$ by 2018 (Figures $4 \mathrm{a}, \mathrm{b}$ ). The overall accuracy and kappa value for the land use classification was observed to be 90.26 to 88.97 and 0.82 to 0.79 , respectively (in Table 6). Land use prediction indicates built-up area would increase to $20.24 \%$ by 2050 (Figure 4c). Therefore, the region is likely to experience urban growth by 2050 with increased density and rise of secondary and tertiary employment sources. Urban areas as per the government of India census definition are region having density more than 5,000 people $/ \mathrm{km}^{2}$. Figure 5 represents the temporal variation in land use classes for the year 2011, 2018, and 2050.

With an urbanization rate of $30 \%$ for the country, APCR is likely to expect a rapid transformation of rural area to urban landscape. The strategic location of Krishna and Guntur district makes the study area well-placed regions in terms of rail and road connectivity. The dissecting trunk lines connect APCR to the nearby metro cities providing favourable conditions for urban transformation along the corridor.

Table 6. Accuracy of Land Use

\begin{tabular}{lll}
\hline Year & Overall accuracy & Kappa value \\
\hline 2011 & 90.26 & 0.82 \\
2018 & 88.97 & 0.79 \\
\hline
\end{tabular}

Guntur is evidence of such a nodal development. It already possesses a strong base for agro-industries, processing clusters and cold chains, also leafing out thousands of indigenous employment opportunities. Guntur is a hub for transport, textile, and agriculture-related products and globally known for its agro-exports (Department of Commerce, 2017). The region may witness a large amount of immigration from the surrounding villages, as it is one of the prominent 'growth centres'. It will offer fair chances of better livelihood due to a progressive social stratification of cultural attribute and equitable educational opportunity.

Tenali is a revenue division in Guntur district that is well known for executing educational services for villages in the vicinity. Duggirala has a large agriculture market yard. It is well known for agro-based trade and commerce. It also falls in busy South-East rail route that can expect rapid growth in an urbanizing scenario. Pedakakani and Thullur mandal are popular for government-aided schools and colleges and can witness future urbanization due to service expansion. Vijayawada, being the only metropolis located in APCR offers an exciting experience of city life with active civic and municipal services. Major growth in the Krishna district is expected around its periphery in a business as usual scenario.

However, absence of systematic planning strategies and inadequate infrastructure will disintegrate the upcoming urban areas in the year 2050. These will struggle for basic needs and are likely to settle for environmentally damaging alternatives. This may lead to higher disaster susceptibility in the region. Sustainable Development Goals (SDGs) and various disaster management frameworks across the globe elaborate upon the need for 'disaster preparedness and adaptive capacity development' as an effective technique to reduce hazard effect. Therefore, the coping capability of APCR region must be such that it matches the proposed complexities of urban development for a guaranteed robust environment.

In APCR, the past flood records indicate the effect of changing climate on monsoonal timeline being shorter and intense. The reoccurrence of severe rainfall events due to cyclones and changing annual monsoons led to unforeseen threats to reservoir capacities, compelling the flood authority to release the water, severely flooding the downstream. During the year 1998, river Krishna received a flood discharge of 93.2 million cusecs and caused alarming situation throughout the flood banks below the Prakasham barrage. The subsequent discharges in 2005 and 2009 were 74 and 111 million cusecs respectively.

The total risk map generated for the study area, as shown in Figure 6 identifies mandals needing proactive adaptation to cope with future urban expansion in APCR. The indicatorbased mapping approach helps in detailing broader set interrelated factors that can affect regional vulnerability to floods. For instance, Mandals in the Guntur district namely Ponnuru, Bhattiprolu, Kolluru, Chebrolu, Durgiala, Tadepalle, Tsunduru lie in a very high-risk zone. They exhibit the poorest capacity to adapt or rejuvenate from extreme situations. The reason to this can be constant lower scores in parameters such as female education, health infrastructure services and number of kutcha houses in the region. These mandals are located on flat terrain exceeding chance of inundations during floods.

Amaravati, composed of Tulluru and Tadepalle mandals have extremely high and high-risk values, respectively. Both the capital city mandals perform poorly for female literacy, health infrastructure, and nearness to the stream which makes highly susceptible flooding disaster. Similarly, Ghantasala, Mopidevei, Movva, and Peddaparupudi mandals within Krishna district exhibit very low endurance for flood-related disasters.

The expected urban growth in the underperforming mandal is a serious threat to resilient and sustainable development. The circumstance will endanger the lives of larger population group to flood risk. Mandals showing extremely low risk and low risk to floods such as Jaggyapeta, Konduru, Nandigama, and Nuzvid share a locational benefit of being placed at a higher elevation. They have a safe distance from the stream and maintain better scores for accessibility, population density, female education, and number of kutcha housing.

The proposed method integrates exposure, sensitivity, and adaptability in a single regional framework plan making way for planners to identify the factors associated with poor disaster resilience. The spatial data representation serves as an interactive platform for the policy makers from varied backgrounds 
(a) Land use statistics for 2011

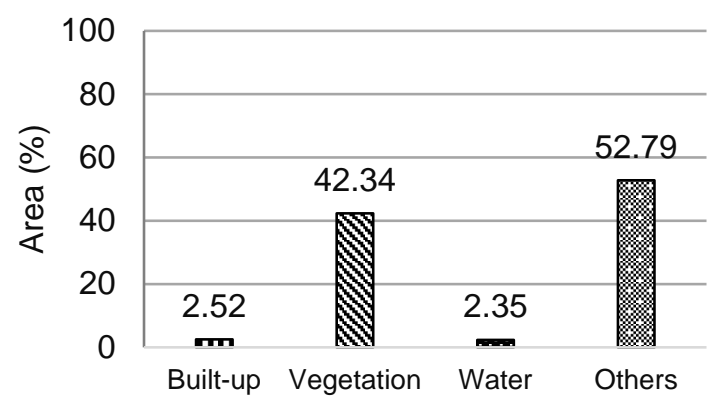

(c) Land use statistics for 2050

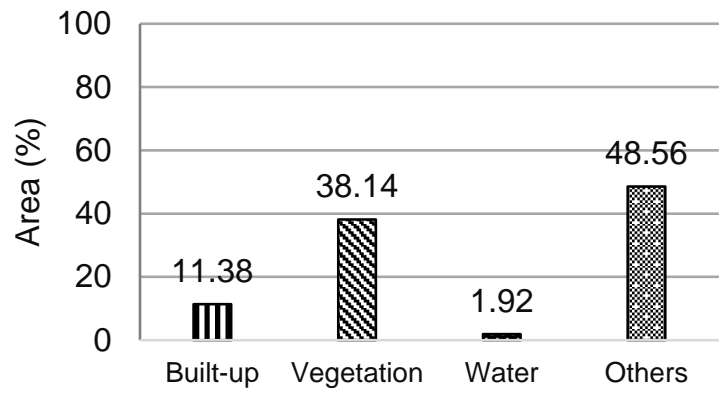

(b) Land use statistics for 2018

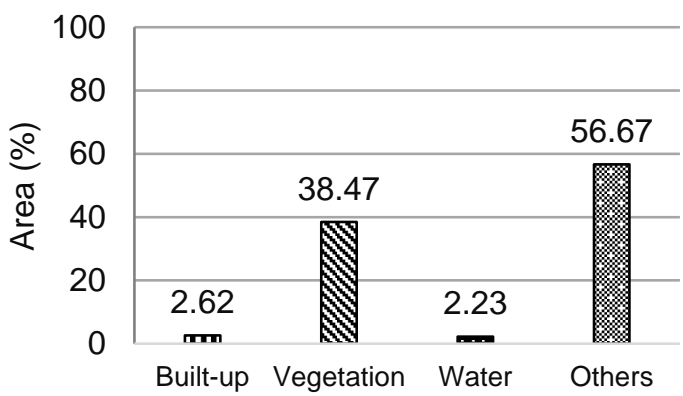

Figure 5. Land use statistics (a) 2011; (b) 2018; (c) 2050.

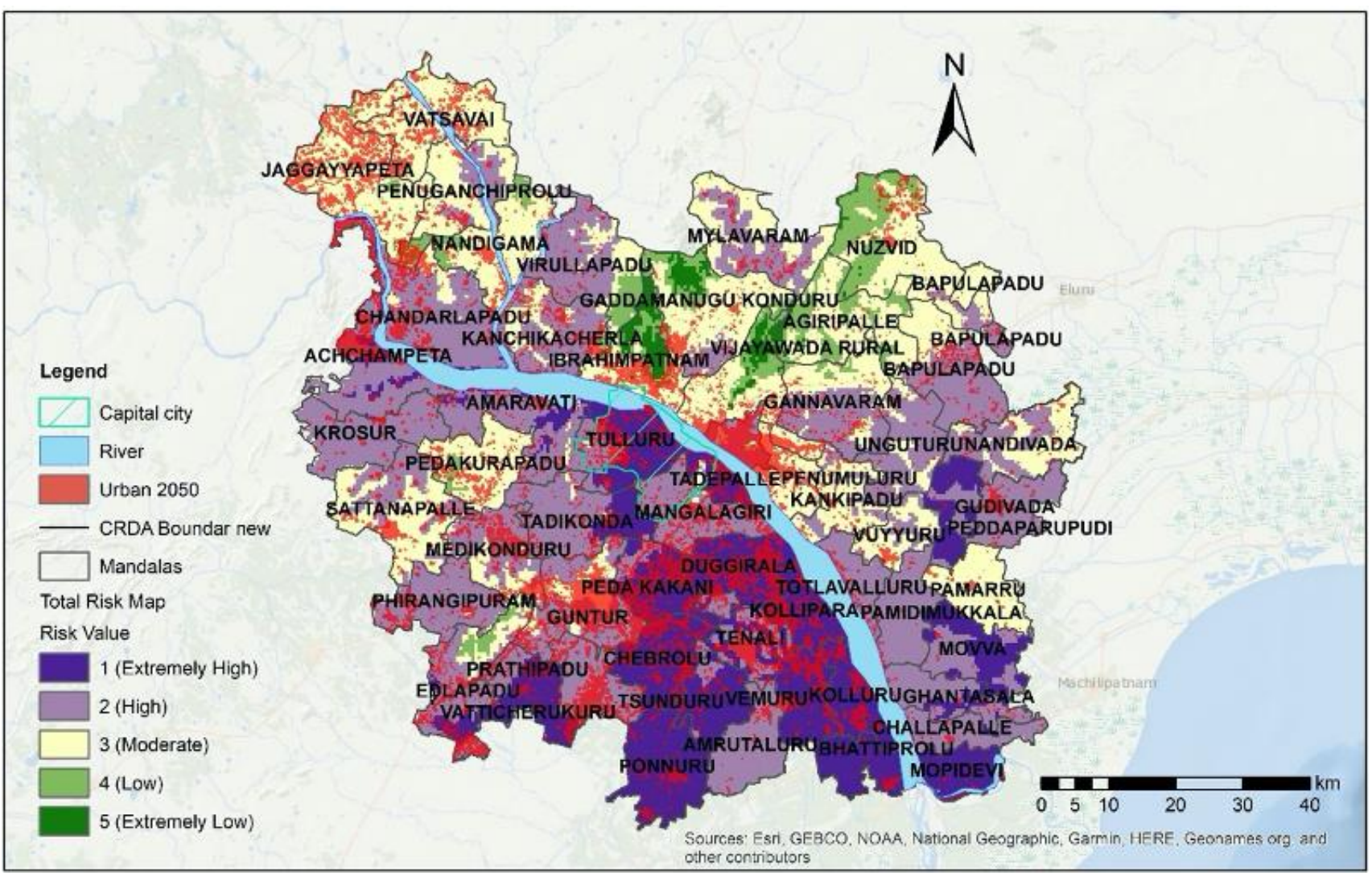

Figure 6. Total risk map. 
to work together for a common good. The individual maps for each of the spatial indicator provides instant information on its status and effect on regional vulnerability. These can guide local level intervention and redirection of funds for enhancing the adapting capacity.

\section{Conclusion}

Adaptation to climate change is important in order to prevent disasters caused due to weather anomalies. Adaptive capacity assessment helps in identifying major threats affecting a region along with differential vulnerability associated to them. The research here, takes a case scenario of newly delineated Andhra Pradesh Capital Region carved out of Krishna and Guntur districts of Andhra Pradesh. The region holds a massive history of floods with them getting more erratic and destructive in recent times. The vulnerability assessment factors were chosen from physical, social, and economic domains on the basis of literature review and data availability. The factor values were normalized based on relative scoring and further ranked as per the likert scale to maintain the uniformity of the analysis. The factors were then prioritized on the basis of pair wise comparison using multi-criteria technique and mapped for spatial analysis. A weighted sum overlay was performed from the obtained weights (or global weights) and the result was superimposed by projected land use map of 2050 giving the 'Total risk map' for the region. Land use classifications and prediction of future growth for the year 2050 using CA modelling technique was useful in generating information for aligning proactive adaptation policies in the upcoming development agenda. For instance, areas with high and extremely high risk values that centre major urban growth as per the projected land use map (areas such as, Chebrolu, Durgiala, Kolluru, Ponnuru, Peda Kakkani, Tadepalle, Tsunduru, and Tenali) requires immediate and strategic intervention in order to a ensure disaster resilient growth in future.

The flood vulnerability analysis also revealed dominance of the social factors in enhancing susceptibility of region due to climate extremes. However, the study does not take into account the upcoming effects that the urban transformation and its policies might have on the local economy. Popularly known as 'rice bowl of India' the Krishna-Godavri basin is one of the most fertile areas in the country contributing signifactly to the state Gross Domestic Product (GDP). Therefore, proposed urban development may undermine job securities of these primary sector employees that consist a significant amount of women population.

Apart from this, the key limitations of analysis were free and authentic spatial data availability. Census 2011 is the most updated population data available for analysis, but a more recent data on socio-economic aspects can give clearer insights of vulnerability. ASTER DEM of resolution $30 \mathrm{~m}$ was used for generation of parameters such as elevation and slope. A higher resolution topographical data can successfully provide bring out the finer details. The study also follows a basic technique of prioritization and hence a greater precision can be worked out through alternative technique. The landuse map of 2050 in the study was predicted using a non-agent based method and use of growth agent can give better urban prediction.

The research emerges as a time-efficient technique to broadly identify spatial vulnerability to floods at a regional scale. The Central Water Commission (CWC) identifies floods to be a major threat in this era of climate change leading to the death of as many as 107,487 people across India over the past seven decades. India, as per the government statistics, accounts for one fifth of global deaths because of floods. The World Bank also points out that the country may face substandardized living condition in coming decades with a six-fold increase in its population exposed to severe flood risk. Therefore, the government can use this method as preliminary assessment for better execution of regional plans/development projects in the areas that require greater resilience against flood hazard. The research can also be elaborated into a multi-hazard aspect, and methodology can be generically used for developing disaster risk maps to prioritise proactive adaptation plans for a region on any chosen scale.

Acknowledgements. We are grateful to (I) NRDMS, Department of Science and Technology, Government of India; (II) Sponsored research in Consultancy cell, Indian Institute of Technology Kharagpur; and (III) West Bengal Department of Higher Education for the financial and infrastructure support.

\section{References}

Akhtar, S. and Farooq, M.I. (2017). A Comparative Study of Uttarakhand and Kashmir Flood in the plight of Natural Disaster. International Journal of Engineering and Management Research, 7(4), 443-450.

Alley, R.B., Marotzke, J., Nordhaus, W.D., Overpeck, J.T., Peteet, D.M., Pielke, R.A., Pierrehumbert, R.T., Rhines, P.B., Stocker, T.F., Talley, L.D., and Wallace, J.M. (2003). Abrupt climate change. Science, 299(5615), 2005-2010. https://doi.org/10.1126/science. 1081056

Andhra Pradesh Capital Region Development Authority. (2017). Facts \& Figures. Andhra Pradesh Capital Region Development Authority. https://crda.ap.gov.in/APCRDADOCS/DataModuleFIles.

Andhra Pradesh Water Resource Development Corporation. (2009). Managing Historic Flood In krishna River Basin - An Experience of Averting Catastrophe. Andhra Pradesh Water Resource Development Corporation (Vol. 91). Retrieved from https://www. Indiawaterportal.org/sites/indiawaterportal.org/files/Managing historic flood in the Krishna river basin_ An experience of averting catastrophe_APWRDC_2009.pdf Accessed 1 Apr 2019.

APWRDC (2009). Managing Historic Flood in Krishna River Basin October Andhra Pradesh, India. https://fdocuments.in/document/ flood-management-book-andhra-pradesh.html

Azad, A.K., Hossain, K.M., and Nasreen, M. (2013). Flood-induced vulnerabilities and problems encountered by women in northern Bangladesh. International Journal of Disaster Risk Science, 4(4), 190-199. https://doi.org/10.1007/s13753-013-0020-z

Balica, S.F., Popescu, I., Beevers, L., and Wright, N.G. (2013). Parametric and physically based modelling techniques for flood risk and vulnerability assessment: a comparison. Environmental Modelling \& Software, 41, 84-92. https://doi.org/10.1016/j.envsoft.2012.11.00

Banholzer, S., Kossin, J., and Donner, S. (2014). The impact of climate change on natural disasters. In Reducing disaster: Early warning systems for climate change, 21-49. https://doi.org/10.1007/978-94017-8598-3_2 
Bharath, H.A., Chandan, M.C., Vinay, S., and Ramachandra, T.V. (2017). Modelling urban dynamics in rapidly urbanising Indian cities. Egyptian Journal of Remote Sensing and Space Science, 21(3), 201-210. https://doi.org/10.1016/j.ejrs.2017.08.002

Bhat, V., Bharath, H.A., and Ramachandra, T.V. (2015). Spatial patterns of urban growth with globalisation in India's Silicon Valley. National Conference on Open Source GIS: Opportunities and Challenges.

Brooks, N. and Adger, W.N. (2005). Assessing and enhancing adaptive capacity. Adaptation Policy Frameworks for Climate Change: Developing Strategies, Policies and Measures, 165-181.

Byravan, S. and Rajan, S.C. (2013). An Evaluation of India's National Action Plan on Climate Change. Retrieved from http://ifmrlead.org/ wp-content/uploads/2016/05/NAPCC\%20Evaluation.pdf.Accessed 19 May 2019.

Census of India. (2011). District Census Handbook Guntur Village And Town Directory. Retrieved from https://censusindia.gov.in/20 11census/dchb/. Accessed 1 May 2019.

Census of India. (2011). District Census Handbook Krishna Village And Town Directory. Retrieved from https://censusindia.gov.in/20 11census/dchb//. Accessed 1 May 2019.

Census of India. (2011b). Population Composition. Census of India https://doi.org/10.1007/s13398-014-0173-7.2

Central Water Comission (CWC). (2015). Water and Related Statistics. Retrieved from http://www.indiaenvironmentportal.org.in//.Access ed 7 May 2019

Connor, R. F. and Hiroki, K. (2005). Development of a method for assessing flood vulnerability. Water Science and Technology, 51(5), 61-67. https://doi.org/10.2166/wst.2005.0109

De, U.S., Dube, R.K. and Rao, G.P. (2005). Extreme weather events over India in the last 100 years. Journal of the Indian Geophysical Union, 9(3), 173-187.

Department of Commerce Government of India (2017). Annual Report 2016-2017: Towards Sustainable and Lasting Growth. Government of India. Retrieved from https://commerce.gov.in/writereaddata/up loadedfile/.

Eiser, J. R., Bostrom, A., Burton, I., Johnston, D.M., McClure, J., Paton, D., van der, P.J. and White, M.P. (2012). Risk interpretation and action: A conceptual framework for responses to natural hazards. International Journal of Disaster Risk Reduction, 1, 5-16. https:// doi.org/10.1016/j.ijdrr.2012.05.002

Engle, N.L. (2011). Adaptive capacity and its assessment. Global Environmental Change, 21(2), 647-656. https://doi.org/10.1016/j. gloenvcha.2011.01.019

Folke, C. (2006). Resilience: The emergence of a perspective for social -ecological systems analyses. Global environmental change, 16(3), 253-267. https://doi.org/10.1016/j.gloenvcha.2006.04.002

GOI (2011). Census of India 2011: Meta Data. Retrieved from https://censusindia.gov.in/2011census/HLO/Metadata_Census_2011. pdf . Accessed 20 Apr 2019.

Gupta, A.K. (2009). Flood disaster mitigation and management: a synthesis and key lessons. Disaster and Development, 3, 163-175.

Hamidazada, M., Cruz, A.M., and Yokomatsu, M. (2019). Vulnerability Factors of Afghan Rural Women to Disasters. International Journal of Disaster Risk Science, 10(4), 573-590. https://doi.org/10. 1007/s13753-019-00227-z

IPCC (2001). Climate Change 2001: Synthesis Report. Retrieved from https://www.ipcc.ch/site/assets/uploads/2018/05/SYR_TAR_full_r eport.pdf

Islam, S. (2017). An assessment of Women Vulnerability for Flooding Hazard and Socio-Economic Condition: A Case Study on Char Gonai of Tepamadhapur Union, Kaunia, Rangpur, Bangladesh. Im- perial Journal of Interdisciplinary Research, 3(4), 96-111.

Lantman, J.V.S., Verburg, P.H., Bregt, A. and Geertman, S. (2011). Land-Use Modelling in Planning Practice, 101, 35-57. https://doi. org/10.1007/978-94-007-1822-7

Lee, Y.J. (2014). Social vulnerability indicators as a sustainable planing tool. Environmental Impact Assessment Review, 44, 31-42. https: //doi.org/10.1016/j.eiar.2013.08.002

Maduri . (2016). The impact of flooding in Bihar, India on women: a qualitative study. Asian Women, 32, 31-52. https://doi.org/10.144 31 /aw.2016.03.32.1.31

MoEF. (2012). State Action Plan On Climate Change. http://moef.gov. in/wp-content/uploads/2017/08/Andhra-pradesh.pdf

Nair, T.B., Sirisha, P., Sandhya, K.G., Srinivas, K., SanilKumar, V., Sabique, L., Nherakkol, A., KrishnaPrasad, B., Jeyakumar, C., Kaviyazhahu, K. and RameshKumar, M. (2013). Performance of the ocean state forecast system at Indian National Centre for Ocean Information Services. Current Science, 105(2), 175-181

Nandargi, S. and Dhar, O. N. (2003). High frequency floods and their magnitudes in the Indian rivers. Journal of the Geological Society of India, 61(1), 90-96. https://doi.org/10.1007/978-94-017-01372-1

Nied, M., Pardowitz, T., Nissen, K., Ulbrich, U., Hundecha, Y. and Merz, B. (2014). On the relationship between hydro- meteorological patterns and flood types. Journal of Hydrology, 519, 3249-3262. https://doi.org/10.1016/j.jhydrol.2014.09.089

Nimish, G., Chandan, M.C., and Bharath, H.A. (2018). Understanding Current and Future Landuse Dynamics with Land Surface Temperature Alterations: a Case Study of Chandigarh. ISPRS Annals of Photogrammetry, Remote Sensing and Spatial Information Sciences, 45, 79-86. https://doi.org/10.5194/isprs-an nals-IV-5-79-2018

Planning Commission. (2011). Faster, Sustainable and More Inclusive Growth: An Approach to the Twelfth Five Year Plan. Retrieved from https://ideas.repec.org/p/ess/wpaper/id4452.html. Accessed 1 March 2019.

Ramachandra, T.V, Bharath, H.A., and Kumar, U. (2012). Conservation of wetlands to mitigate urban floods. Journal of Resources, Energy \& Development, 9(1), 1-22. https://doi.org/10.3233/RED120001

Rufat, S., Tate, E., Burton, C.G. and Maroof, A.S. (2015). Social vulnerability to floods: Review of case studies and implications for measurement. International Journal of Disaster Risk Reduction, 14, 470-486. https://doi.org/10.1016/j.ijdrr.2015.09.013

Saaty, T.L. (2008). Decision making with the analytic hierarchy process. International Journal of Services Sciences, 1(1), 83-98. https://doi.org/10.1504/IJSSCI.2008.017590

Sarmah, T. and Das, S. (2018). Urban flood mitigation planning for Guwahati: A case of Bharalu basin. Journal of Environmental Management, 206, 1155-1165. https://doi.org/10.1016/j.jenvman.20 17.10.079

Smit, B. and Wandel, J. (2006). Adaptation, adaptive capacity and vulnerability. Global Environmental Change, 16(3), 282-292. https:// doi.org/10.1016/j.gloenvcha.2006.03.008

Tripathi, P. (2015). Flood disaster in India: an analysis of trend and preparedness. Interdiscip J Contemp Res, 2(4), 91-98.

UNDP. (2013). Gender and Disaster Risk Reduction. Retrieved from www.undp.org/gender. Accessed 4 March 2019

Wang, Z., Wang, H., Huang, J., Kang, J., and Han, D. (2018). Analysis of the public flood risk perception in a flood-prone city: The case of Jingdezhen city in China. Water, 10(11), 1577. https://doi.org/10. 3390/w10111577

Wisner, B., Blaikie, P.M., Blaikie, P., Cannon, T. and Davis, I. (2004). At Risk: Natural Hazards, People's Vulnerability and Disasters. Routledge. https://doi.org/10.4324/9780203974575 